\title{
Oral health quality of the workers of a telemarketing company and their satisfaction with the treatments provided by the corporative dental insurance plan
}

\author{
Cristiane dos Santos Martins ${ }^{1}$, Dagmar de Paula Queluz² \\ ${ }^{1}$ Prefeitura Municipal de Uberlândia, Health Secretary, Area of Oral Health, Uberlândia, MG, Brazil \\ ${ }^{2}$ Universidade de Campinas - UNICAMP, Piracicaba Dental School, Department of Community Dentistry, Piracicaba, SP, Brazil
}

Received for publication: November 10, 2015 Accepted: December 13, 2015

Correspondence to: Dagmar de Paula Queluz Departamento de Odontologia Social Faculdade de Odontologia de Piracicaba - UNICAMP Avenida Limeira, 901, CEP: 13414900

Piracicaba, SP, Brasil

Phone: +55 1921065277

E-mail: dagmar@fop.unicamp.br

\begin{abstract}
Aim: To evaluate the oral health quality of the workers of a telemarketing company and their satisfaction with the dental treatments provided by the corporative dental insurance plan. Methods: Data collection was by an online intranet questionnaire on dental service providers from Uberlândia/MG and Campinas/SP. It was addressed to 6000 associates, with objective and subjective questions, comprising the level of the telemarketing operators' oral health, dental needs, satisfaction with dental care providers and the importance of having the laboral dental services provided by the company. Results: After analysis of the results, we observed that: $57.52 \%$ of the workers required improvement in their oral health and $56.03 \%$ mentioned prevention as the largest need, $66.70 \%$ use the dental providers' services, but only $31.34 \%$ were satisfied with them. Conclusions: The results underscore that the workers have an intermediate level of dental needs, with prevention as top importance. Additionally, establishment of a basic attention program inside the company would increase the satisfaction and adhesion indexes of providers and the workers' oral health.
\end{abstract}

Keywords: oral health; telemarketing; operators; occupational health.

\section{Introduction}

Occupational Health is a technical area of Public Health that seeks to intervene in the relationship between the production system and health, in order to promote work that dignifies instead of demeaning the man. Its mission is to assist in structuring a society that promotes health through workspaces ${ }^{1}$.

It is a known fact that oral modifications compromise the individual's general health, interfering negatively in his/her quality of 1 ife ${ }^{2-8}$ and affecting the productive activity of the worker ${ }^{2-7}$.

The Laboral Dentistry in the context of a company leads to an improvement of oral health to the compatibility of labor activity with oral health ${ }^{9}$, providing health quality and therefore increasing productivity and developing a primary care and preventive oral health ${ }^{10-13}$.

In the last few years, telemarketing activities have been provided in what are commonly called call centers, or telemarketing centers. This economic sector 
employs millions of workers all over the world and has organized structures for dealing with the public ${ }^{14-22}$. The expansion of the telemarketing sector in the Brazilian economy has been very consistent. Telemarketing involves an intense use of technological tools and also reflects the consequences of the transformation of the capital production ways.

Cordeiro $^{22}$ investigated and analyzed how the working activity in the call centers is related to the health of the operators. The results are similar to those of other studies ${ }^{14-21}$, as the operators experienced a process of precarious work with impacts on their health and a great increase of occupational diseases.

Medeiros and Bijella ${ }^{23}$ studied the development of dental care programs for workers, suggesting criteria for changes in the planning and routine care. To set priorities for attention to oral health, they can be applied to the group for the same reasons evoked when school programs are established, considering that the workers accumulate greater needs, in addition to the rehabilitation aspects. The authors concluded that the provision of dental services to worker groups should be available, preferably in the workplace. It is also important to plan a program focused on the needs of the workers, with a prior dental census to establish the priorities.

The importance of the dentist in the occupational health team was highlighted 1972 by Nogueira ${ }^{24}$, who described various oral pathologies resulting from occupational diseases triggered by mechanical, physical, biological and chemical agents.

In order to demonstrate the need for maintenance of dental services of a company, Gomes and Magalhães ${ }^{25}$ analyzed the results of the survey of dental needs conducted in 1977, among the employees of the Brazilian Federal Railway Network. The authors based on evidence obtained by the epidemiological study using medical records for verification of DMFT and other problems in the oral cavity from the dental care planning point of view. They concluded that the oral census is of great value in business Dentistry, as it constitutes the only resource that has professional application for preventative Dentistry. This procedure results in lower absenteeism and increased productivity, favoring the company and the employee ${ }^{21,25-31}$.

In 1999, the worker's oral health was recognized as a new specialty for dentists ${ }^{32}$. The authors recommend that this new field should address the epidemiology and pathology of occupational diseases, seeking to prevent the harmful effects of working conditions and their influence on health.

Many systemic diseases have oral manifestations, and Hollister and Weintraub ${ }^{33}$ conducted a study seeking to associate oral health to systemic health, quality of life and economic productivity. The results showed that oral health conditions have a direct influence on systemic health and people's quality of life as well as on economic productivity, noting that the oral pathologies are responsible for the loss of working days.

Ferreira $^{34}$ highlights the value of oral health in companies, covering health promotion and mentioning which procedures are used in various work environments. Warning also that caries and other oral complications are responsible for $20 \%$ of the service absenteeism, production drop and generation of widespread infections.

With the ongoing globalization of the economy there is an increase in global competitivity and to achieve success and survival, entrepreneurs are increasingly looking for measures to facilitate the productivity ${ }^{35-39}$ and satisfaction of members, the actions of Engineering and Safety medicine Specialized Services contribute to improving the health and cooperated to improve the company's competitivity in the global market conditions. The dentistry is present in this context of globalization, in addition to curative treatment to cooperative members, adds preventive measures ${ }^{17,40}$ within the company ${ }^{41-42}$, respecting the needs that each site presents.

Health promotion programs at the workplace tend to have greater adherence if compared with those developed elsewhere ${ }^{35-39}$.

Silva \& Souto published three studies ${ }^{43-45}$ on healthcare service model occupational dentistry, defending the idea that dental programs in the company do facilitate access and preserve the oral health of members. They emphasize the importance of admission and periodic dental examinations as well as participation in educational and preventive campaigns. They also emphasize that the company should implement the dental care for workers, since good health status is important for improving productivity.

The analysis of the responses can trace a curative welfare profile offered by the company to its employees, assessing the real need for them, and the degree of satisfaction with the existing accreditation and developing prevention programs in the company. In this way Labor Dentistry may be introduced in the company and highlight the work of occupational dentist within the promotion scenario and surveillance of the oral health and welfare by accredited dentists, suggesting the needed preventing programs for its members ${ }^{10-13}$.

The purpose of this research was to evaluate the oral health quality of the workers of a telemarketing company and their satisfaction with the dental treatments provided by the corporative dental insurance plan.

\section{Material and methods}

\section{Study Area}

The company chosen to develop this research presents some parameters by which to assess accreditations, i.e., it has a security team specialized in health and labor medicine and offers cooperative dental care plan. It is a telemarketing located in Uberlandia-MG and Campinas-SP (both in Brazil) and is now one of the most advanced telemarketing companies in Latin America (from 2005 to 2015).

The company offers a variety of services and solutions, with 3 service locations in a $2,5000 \mathrm{~m}^{2}$ area, generates 6,000 direct and 1,500 indirect jobs and performs activities 24 hours a day, 7 days a week. Currently the company has two dental services providing curative care to the insured outside the work environment. The cooperative associated members are 2000 workers. 
The target research population comprises a majority of young people (aged 18-35 years), with an incomplete college education. This information came from the human resources department of the company.

The company network has a business design, in which the structure is divided into central results, which act as small businesses within a large company.

The company chosen for the development of research is management model called Enterprise Network in 1989, hence the difference in changing the name "jobs" or "employees" to "associates" for the associate begin to feel and be regarded as a partner in business. Although he does not invest capital in the activity, he invests his intelligence and his commitment so that everyone wins. Associates become a cooperate when he joins the dental plan or medical plan from the company network.

\section{Study Design and Data Collection}

This is a cross-sectional, descriptive and quantitative study. It consisted of applying an online intranet questionnaire with 10 objective questions (closed) and one subjective question (open). The questions addressed aspects on the level of oral health of associated members, the level of dental needs, the degree of satisfaction with the accredited services and the importance of having the laboral dentistry acting within the company. The inclusion criterion was to fill out the questionnaire.

In companies of Uberlândia/MG and Campinas/SP, the questionnaire along with the Informed Consent Form were made available on the intranet for 6000 associates for 10 days, from the second half of August 2006. The associates had total freedom to refuse to participate or withdraw their consent at any stage of the research, without any penalty or loss. Full confidentiality and privacy of the individual responses was assured. They were informed of the importance of their contribution to the evaluation of the dental care provided to them.

\section{Data Analysis}

After data tabulation descriptive statistical analysis using SAS software version 9.1 was performed and the results were expressed as absolute and relative frequencies in tables.

The variables were compared by checking the existence of association. One test was used to check for association between variables: the Chi-square test to verify the independence of the questions was conducted, and calculating the significance of the test, i.e., its p-value. This procedure was used since frequencies lower than 5 occurred, which invalidated one assumption of the squared chi-test. Thus, as the test was performed, it does not affect the results. When the p-value is less than 0.05 , the hypothesis that the question has a dependent relationship is accepted and when the p-value is greater than 0.05 , it confirms the independence of the evaluated questions.

The results of the association among variables were performed at a $5 \%$ significance level $(\mathrm{p}<0.05)$.

\section{Ethical Considerations}

This research was approved by the Ethics Committee of the Piracicaba Dental School - UNICAMP, under Protocol number 090/2006.

\section{Results}

The company has 6000 members, and 2000 of them use the corporative dental insurance plan (associates). From this total, 871 answered the intranet questionnaires addressing aspects under the level of "Oral health quality of the associated members" (Table 1), the degree of "Level of satisfaction with services provided by the corporative dental insurance plan providers to the associated members" (Table 2).

The open question, where associated members justified WHY they are favorable $(\mathrm{n}=836,95.98 \%)$ is in Table 2 . The analysis of the responses was done by reading and rating 5 phrases of the issue (Figure 1).

The results from the association between variables were calculated (Tables 3, 4 and 5).

\section{Discussion}

Usually the large companies are those that enable greater benefits to its employees, among which dental services. In Brazil, this benefit is not mandatory, leaving it to the company to decide its implementation or not. The studied company offered Dental Accredited covenants, but it is necessary to impove the covenant; also the associate members have to learn more and appreciate more their general and oral health (Tables 1 and 2).

Evaluating the Table 3 its was found that $27.6 \%$ $(n=240)$ consider that their oral health needs to improve and the main dental need is prevention; 29.4\% $(n=256)$ of those who consider that need to improve their oral health have participated in educational lectures and $39.2 \%(n=341)$ make use of the dental covenant; $96.0 \%$ would like that their workplace/company developed a primary care program and prevention oral health to the associates.

The lack of total satisfaction with the dental service covenant along with the perception of oral health quality associated revealed intermediate level. Generally, dissatisfaction is due to the fact the dentists work in private practice offices and not within the company, which generates for the associated members need to be away from their working activities. Hampers also that it has a control of accredited patients because at the telemarketing company under research, due to bureaucracy of accredited services, are not made pre-employment ${ }^{46}$ or periodic dental examinations ${ }^{32,47,48}$, which contributes to no control of first need cases, and not establish a profile of needs to associated members. Without the encouragement and periodic attention within the company it is difficult to create hygiene habits and prevention ${ }^{35-39}$ by the associated members. The value of the job contrasts with the negative repercussions on health.

The recommended profile for dentistry should be 
Table 1: Distribution of absolute and relative frequency of variables according the "Oral health quality of the associated members", 2006. $(n=871)$

\begin{tabular}{|c|c|c|}
\hline Variables & & n (\%) \\
\hline \multirow[t]{3}{*}{ How do you consider your oral health? } & Satisfatory & $310(35.59)$ \\
\hline & Need to improve & $501(57.52)$ \\
\hline & Unsatisfatory & $60(6.89)$ \\
\hline \multirow{3}{*}{$\begin{array}{l}\text { When you are looking for dental treatment which is } \\
\text { your greatest need? }\end{array}$} & Cleaning, scraping, bicarbonate jet and fluoride & $488(56.03)$ \\
\hline & Treatment of caries, canal and crowns & $267(30.65)$ \\
\hline & Gingival treatment and extractions & $17(1.95)$ \\
\hline \multirow[t]{3}{*}{ How often do you brush your teeth daily? } & Only after wake up & $133(15.27)$ \\
\hline & After meals & $727(83.47)$ \\
\hline & Only at bedtime & $11(1.26)$ \\
\hline \multirow[t]{2}{*}{ Have you had any guidance on oral hygiene? ${ }^{*}$} & Yes. As for brushing mode & 711 \\
\hline & Yes. As for flossing & 506 \\
\hline $\begin{array}{l}\text { Have you participated in any lecture about the } \\
\text { importance of oral health? }\end{array}$ & No & $380(43.63)$ \\
\hline \multirow{7}{*}{$\begin{array}{l}\text { What subjects you would be interested to be } \\
\text { addressed in your company by preventive lectures } \\
\text { about oral health? * }\end{array}$} & Prevention: dental caries and gum disease & 504 \\
\hline & Oral cancer & 546 \\
\hline & Oral health of women at all stages of their life & 427 \\
\hline & Occupational diseases causing oral manifestations & 414 \\
\hline & Stress as a cause of oral health problems & 554 \\
\hline & Systemic diseases and their oral manifestations & 359 \\
\hline & Others & 50 \\
\hline
\end{tabular}

* more than one alternative answered

Table 2: Distribution of absolute and relative frequency of variables according the "Level of satisfaction with services provided by the corporative dental insurance plan providers to the associated members", 2006. $(n=871)$

\begin{tabular}{|c|c|c|}
\hline Variables & & n (\%) \\
\hline \multirow{2}{*}{ Do you make use of the dental covenant? } & Yes & $581(66.70)$ \\
\hline & No & $290(33.30)$ \\
\hline \multirow[t]{3}{*}{$\begin{array}{l}\text { Which of the following are your dental services provided } \\
\text { by the covenants. }\end{array}$} & $\begin{array}{l}\text { "The more often I go to the dentist, } \\
\text { the more need for treatment. Each } \\
\text { treatment done, generates a more } \\
\text { complex treatment." } \star *\end{array}$ & $257(29.51)$ \\
\hline & $\begin{array}{l}\text { "The more often I go to the dentist, } \\
\text { the less treatment is needed." } \star \star \star\end{array}$ & $550(63.15)$ \\
\hline & No answer & $64(7.34)$ \\
\hline \multirow[t]{4}{*}{ Level of satisfaction with the dental service provider. } & Satisfatory & $273(31.34)$ \\
\hline & Need to improve & $380(43.63)$ \\
\hline & Unsatisfatory & $138(15.84)$ \\
\hline & No answer & $80(9.19)$ \\
\hline Would you like that your company developed a primary & Yes & $836(95.98)$ \\
\hline \multirow[t]{2}{*}{ care program and prevention oral health? } & No & $35(4.02)$ \\
\hline & WHY? & \\
\hline
\end{tabular}

** increases the need. $\quad$ *** reduces the need

preventive, bringing the concept of oral health not only to the teeth, but to the person's quality of life ${ }^{2-8}$. Thus, attention to oral health should be directed to all ages and specific populations. With regard to workers, most of them have a workload that hampers demand for traditional health services, and there is a resistance of businessmen to facilitate departures and absences even for health reasons. Therefore, it justifies the preference for deployment of services and dental benefits at the company premises ${ }^{40-42}$.

According studies ${ }^{10-13,49}$, there are good reasons to health promotion activities at the workplace and points out the factors: when awake, the individual spends most time at the workplace; persistent imbalances in worker health damage the operational efficiency of both the individual and the 


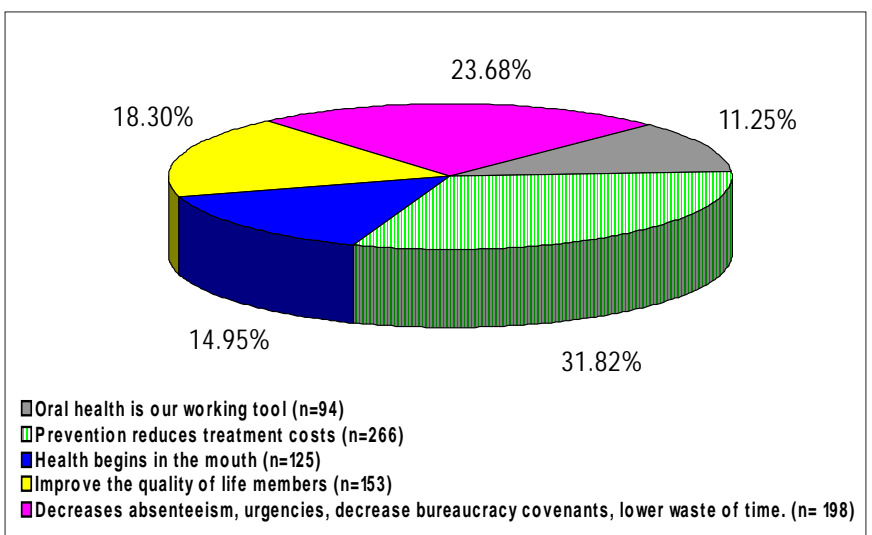

Fig.1: Favourable creating a primary care program and prevention oral health care within the company $(n=836)$.

company, and may produce illness or accidents, without disregarding the practice of unhealthy lifestyles; the company's policy and its regulations and rules can affect health; it is easier to establish more defined groups priorities; short, medium and long term benefits may arise from these programs, like drop in absenteeism; reduction of spending on welfare care and improvement of the well being and employee satisfaction.

According to the Tables 1-5 and Figure 1 from this research, it was possible to outline the profile of the studied company. The sample comprises young adults, with an average high-level awareness, where the main dental needs are prevention and primary care services. This means that only the prevention service has solved much of their needs. Second is the need for "basic" treatments such as dentistry, endodontics and fixed prostheses, it shows that with an initial dental care along with periodic controls, the costs for the company and associated members should be more accessible and as a result increase adherence to accredited services.

The fact that associated members need only choose preventive services by $96 \%$ in order to develop a permanent primary care program within the company, shows the level of awareness and commitment that is associated with oral health. Thus, company and associated members only have to gain with improved quality of life.

It became clear during the research that the greatest concern

Table 3: Distribuition of "How do you consider your oral health?" by some others variables

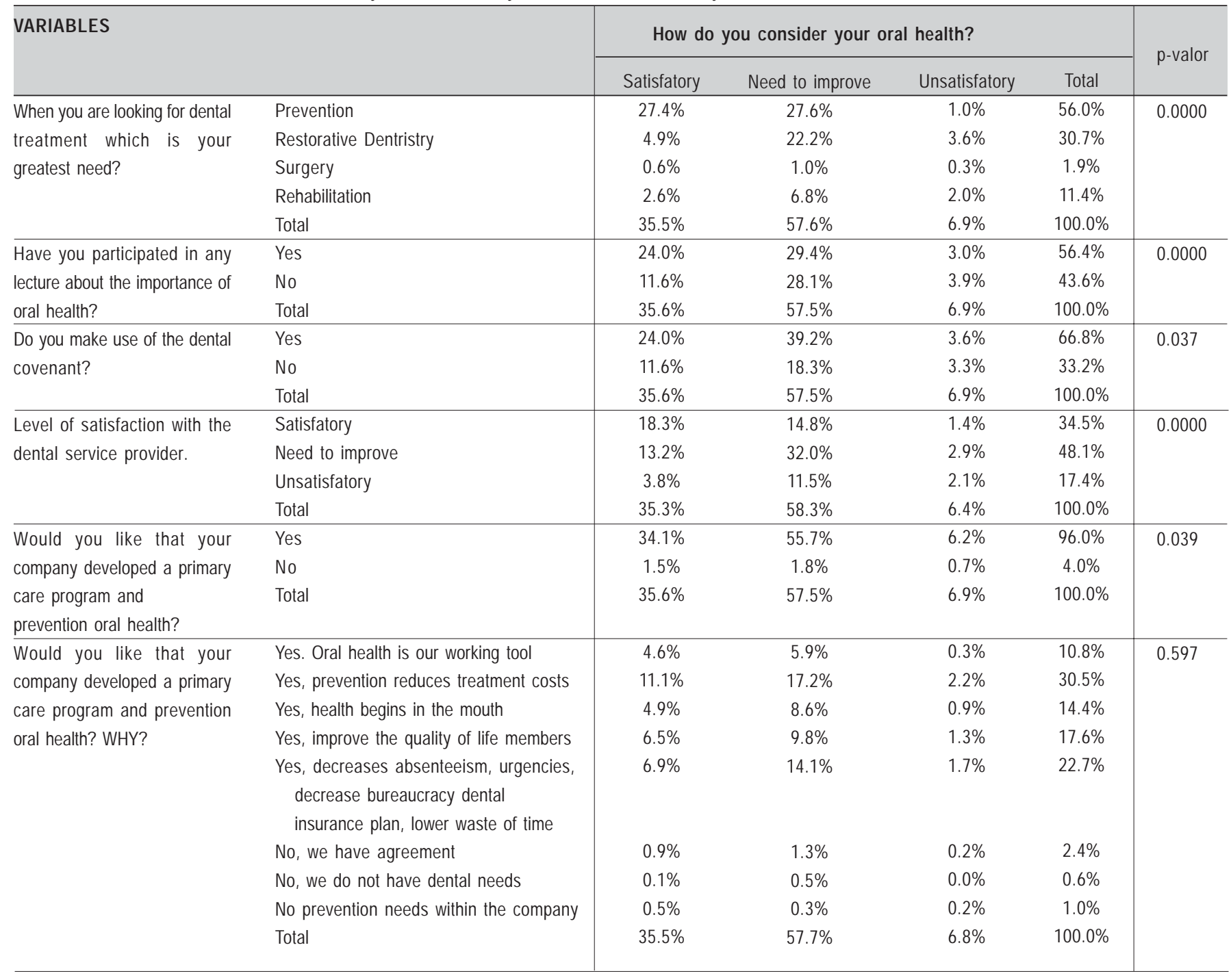


Table 4: Distribuition of "Degree of satisfaction with the provider of dental service" by some other variables.

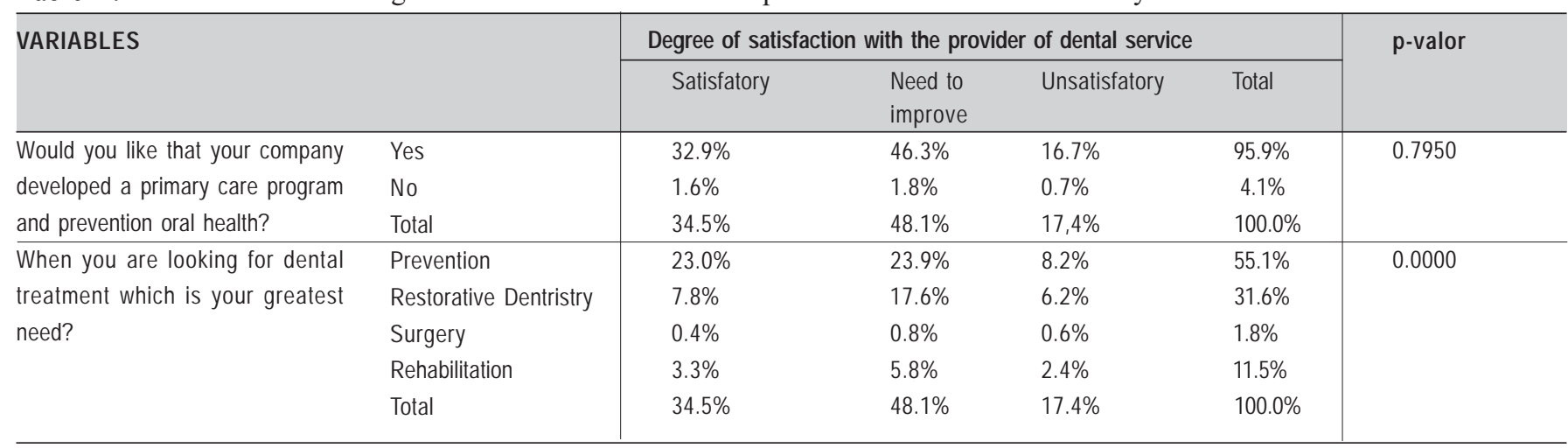

Table 5: Distribuition of "Do you make use of the dental covenant?" by some others variables.

\begin{tabular}{|c|c|c|c|c|c|}
\hline \multirow[t]{2}{*}{ VARIABLES } & & \multicolumn{3}{|c|}{$\begin{array}{l}\text { Do you make use of the dental } \\
\text { covenant? }\end{array}$} & \multirow[t]{2}{*}{ p-valo } \\
\hline & & Yes & No & Total & \\
\hline \multirow{4}{*}{$\begin{array}{l}\text { Degree of satisfaction with the } \\
\text { provider of dental service }\end{array}$} & Satisfatory & $26.3 \%$ & $8.2 \%$ & $34.5 \%$ & \multirow[t]{4}{*}{0.0090} \\
\hline & Need to improve & $36.2 \%$ & $11.9 \%$ & $48.1 \%$ & \\
\hline & Unsatisfatory & $11.0 \%$ & $6.4 \%$ & $17.4 \%$ & \\
\hline & Total & $73.5 \%$ & $26.5 \%$ & $100.0 \%$ & \\
\hline \multirow{3}{*}{$\begin{array}{l}\text { Would you like that your company } \\
\text { developed a primary care program } \\
\text { and prevention oral health? }\end{array}$} & Yes & $63.8 \%$ & $32.2 \%$ & $96.0 \%$ & \multirow[t]{3}{*}{0.5890} \\
\hline & No & $2.9 \%$ & $1.1 \%$ & $4.0 \%$ & \\
\hline & Total & $66.7 \%$ & $33.3 \%$ & $100.0 \%$ & \\
\hline
\end{tabular}

of associated members of the telemarketing company is the stress causing disorders in oral health, due to the pressure ${ }^{14-22}$ for increased production.

According to some studies ${ }^{10-13,26,29,30,49,50}$ Dentistry should be part of occupational health concerns, it is necessary to integrate it to other areas, providing better health to those who move the company with their workforce.

For the associated members of Telemarketing Company is important the role of the dentist within the company because:

- "This professional would know how to develop strategies that would prevent oral diseases and costly future treatments."

- "The professional within the company could act as an expert, like welfare in an emergency, as an important part in maintaining the incentive to oral care, avoiding absenteeism due to bureaucracies accredited by the company."

- "The dentist's work within the company would care for the associated quality of life bringing satisfaction to both company and to the cooperative."

- "The dentist should make the health team work because: health begins at the mouth."

- "The smile is our working tool."

In conclusion, the analysis of the oral health quality of the telemarketing company associates and their level of satisfaction with the treatments provided by coporrative dental insurance plan revealed that they have a intermediate degree of dental care needs, being the prevention of utmost importance and the creation of a basic attention program inside of the company would increase the satisfaction and adhesion rates of accredited and the associate's oral health.

\section{References}

1. Santos EJ, Queluz DP. Factors involved in dentistry absenteeism since the foundation of the Labor Court from 1986 to 2008. Braz J Oral Sci. 2012; 11: 492-504.

2. Quandt SA, HiottAE, Grzywacz JG, Davis SW, Arcury TA. Oral health and quality of life of migrant and seasonal farmworkers in North Carolina. J Agric Saf Health. 2007; 13: 45-55.

3. Macedo CG, Queluz DP. Quality of life and self-perceived oral health among workers from a furniture industry. Braz J Oral Sci. 2011; 10: 226-32.

4. Lacerda JT, Ribeiro JD, Ribeiro DM, Traebert J. [Prevalence of orofacial pain and its impact on the oral health-related quality of life of textile industries workers of Laguna, SC, Brazil]. Cien Saude Colet. 2011; 16: 4275-82. Portuguese.

5. Guerra MJC, Greco RM, Leite ICG, Ferreira EF, Paula MVQ. Impact of oral health conditions on the quality of life of workers. Cienc Saude Colet. 2014; 19: 4777-86.

6. Batista MJ, Perianes LB, Hilgert JB, Hugo FN, Sousa Mda L. The impacts of oral health on quality of life in working adults. Braz Oral Res. 2014; 28 : 1-6.

7. Andrade RD, Barbosa DG, Meyer C, Teixeira CS, Beltrame TS, Felden EPG. Quality of life of telemarketers: An analysis with the Whogol-Br. Cienc Trab. 2015; 17: 177-81.

8. Bilic S, Blomberg I, Burry K, Chong E, Yeung E, Ariyawardana A. Oralhealth-related quality of life of dental patients: a hospital based study in far north Queensland,Australia. J Investig Clin Dent. 2016. doi: 10.1111/jicd.12216. [Epub ahead of print]

9. [Brazilian Federal Dentistry Council CFO-22/2001 and CFO-25/2002]. [cited 2015 Aug]. Available from: http://www.cfo.org.br. Portuguese.

10. Queluz DP. Labour dentistry: a new specialty in dentistry. Braz J Oral Sci. 2005; 4: 766-72.

11. Mendes A, Azevedo G. Labor Dentistry, value specialty. Rev Protecao. $2007 ; 64$. 
12. Queluz DP. [Multidisciplinary Labour Dentistry collaborating with the oral health of workers]. In: Silva E, Martins I. [Dental work: construction and knowledge]. Rio de Janeiro: Rubio; 2008. p. 91-109. Portuguese.

13. Perin PCP, Sales-Peres SHC, Sales-Peres A, Sales-Peres AC, Perin LFMG. [The importance of teaching work dentistry in the graduation of odontology]. Rev Fac Odontol Lins. 2012; 22: 39-45. Portuguese.

14. Batt R, Doellgast V, Know H. The U.S. call center industry 2004: national benchmarking report. Ithaca: Cornell University; 2004.

15. Venco S. [Call centers: 19 th century factory in 21 st century services]. Rev Bras Saude Ocup. 2006; 31: 7-18. Portuguese.

16. Oliveira SS, Brito JC. [The managerial dimension of the work and the debate on standards and values in telemarketing]. Trab Educ Saude. 2011; 9(suppl 1): 265-84. Portuguese.

17. Wolfenden L, Wiggers J, Paul C, Freund M, Lecathelinais C, Wye P, Gillham K. Increasing the use of preventative health services to promote healthy eating, physical activity and weight management: the acceptability and potential effectiveness of a proactive telemarketing approach. BMC Public Health. 2012; 12: 953.

18. Cavaignac $\mathrm{MD}$. The resistance strategies of telemarketing operators against the offensives of capital. Rev Katálysis. 2013; 16: 155-64.

19. Takahashi LT, Sisto FF, Cecilio-Fernandes D. [Work-related stress vulnerability assessment in telemarketing operators]. Rev Psicol Organ Trab. 2014; 14: 336-46. Portuguese.

20. Ricci MG, Rachid $A$. [Labor relations in the call center service]. Gestao Prod. 2013; 20: 192-203.

21. Ziliotto DM, Oliveira BO. [Work organization in call centers: implications for operators' mental health]. Rev Psicol Organ Trab. 2014; 14: 169-79. Portuguese.

22. Cordeiro BK. [The work at Call Center: worker health and its relationship with activity] [Master's degree disseration]. Rio de Janeiro: Universidade Federal Fluminense, Instituto de Ciências Humanas e Filosofia; 2011. Portuguese.

23. Medeiros EPG, Bijella VT. [Bases for organizing programs for dental workers]. Rev Bras Odontol. 1970; 27: 303-11. Portuguese.

24. Nogueira DP. [Dentistry and Occupational Health]. Rev Saude Publica. 1972; 6: 211-23. Portuguese.

25. Gomes EB, Magalhães $\mathrm{H}$. [Oral census in company: its importance in the planning of dental care]. Odontol Mod. 1980; 7: 31-8. Portuguese.

26. Peres SHCS, Peres AS, Oliveira FT, Adachi A, Silva AL, Morandini ACF et al. [Absenteeism: a revision of the literature about the absence to the work related to the dentistry]. Rev OdontolAracatuba. 2006; 27: 96-100. Portuguese.

27. Kuoppala J, Lamminpaa A, Husman P. Workhealth promotion, job wellbeing, and sickness absences - a systematic review and meta-analysis. J Occup Environ Med. 2008; 50: 1216-27.

28. Lacerda JT, Traebert J, Zambenedetti ML. [Orofacial pain and absenteeism in workers of the metallurgic and mechanics industry]. Saude Soc. 2008; 17 : 182-91. Portuguese.

29. Nardi A, Michel-Crosato E, Biazevic MGH, Crosato E, Pizzatto E, Queluz DP. Relationship between orofacial pain and absenteeism among workers in Southern Brazil. Braz J Oral Sci. 2009; 8: 50-4.

30. Macedo CG, Queluz DP. Medical and dental absenteeism in workers from a furniture industry in Itatiba, SP, Brazil. Braz J Oral Sci. 2010; 9: 443-8.

31. Miotto MHMB, Silotti JCB, Barscellos LA. [Dental pain as the motive for absenteeism in a sample of workers]. Cienc Saude Colet. 2012; 17: 135763. Portuguese.

32. Araujo ME, Gonini Júnior A. WWorker oral health: the admission examinations and periodic as a system of health information]. Odontol Soc. 1999; 1:15-8. Portuguese.

33. Hollister MC, Weintraub JA. The association of oral status with systemic health, quality of life, and economic productivity. J Dent Educ. 1993; 57: 901-12.

34. Ferreira RA. [The value of oral health in companies]. Rev Assoc Paul Cir Dent. 1995; 49: 96-107. Portuguese.

35. Almeida TF, Vianna MIP. [Epidemiology role in worker oral health actions planning]. Saude Soc. 2005; 14: 144-54. Portuguese.

36. Gomes AS, Abegg C. [The impact of oral health on daily performance of municipal waste disposal workers in Porto Alegre, Rio Grande do Sul State, Brazil]. Cad Saude Publica. 2007; 23: 1707-14. Portuguese.
37. Brito JC, Neves MY, Oliveira SS, Rotenberg L. [Health, subjectivity and work: the clinical and gender approaches]. Rev Bras Saude Ocup. 2012; 37: 316-29. Portuguese.

38. Silva AMTB, Medeiros UV. [The role of dentistry at work on worker's health]. Rev Bras Odontol. 2013; 70: 104-8. Portuguese.

39. Ab-Murat N, SheihamA, Tsakos G, Watt R. Periodontal treatment needs and workforce requirements: comparisons between the normative and sociodental approaches using different skill mix models. Community Dent Oral Epidemiol. 2015; 43: 106-15.

40. Fishwick MR, Ashley FP, Wilson RF. Can a workplace preventive programme affect periodontal health? Brit Dent J. 1998; 184: 290-3.

41. Lido YJVL, Queluz DP. [Analysis of dental care provided by companies in the metropolitan region of Campinas]. Odonto 2010; 18: 6-10. Portuguese.

42. Lima LS, Araujo MS, Castro PP, CAngussu MCT. [Oral health status of industrial workers included in Corporate Oral Health Program]. Rev Bras Saude Ocup. 2015; 40: 137-46. Portuguese.

43. Silva RB, Souto DF. [Of care service model occupational dentistry. First part]. Odont Mod. 1983; 10: 36-9. Portuguese.

44. Silva RB, Souto DF. [Of care service model occupational dentistry. Second part]. Odont Mod. 1983; 10: 39-45. Portuguese.

45. Silva RB, Souto DF. [Of care service model occupational dentistry. Third part]. Odont Mod. 1983; 10: 27-30. Portuguese.

46. Araujo TR, Queluz DP. Pre-employment exam analysis of a military company and its relation to oral health. Braz J Oral Sci. 2013. 12: 339-44.

47. Olival ARB, Charone S, Groisman S. [The importance of occupational dentistry examination: the propose of dentistry prontuary]. Rev Odontol Univ Cidade Sao Paulo. 2008; 20: 37-45. Portuguese.

48. Brasil, 2012. [Decree number 6856 of May 25, 2009. Legislation on frequency of health examinations]. Available from: http: //www2.camara.leg.br/legin/ fed/decret/2009/decreto-6856-25-maio-2009-588402-norma-pe.html. Portuguese.

49. Mazzili LEN. [Labor Dentistry]. 2. ed. São Paulo: Santos; 2007. Portuguese.

50. Midorikawa ET. [Odontology in worker's health as a new professional specialty: definition of the activity field and functions of the surgeon dentist in worker's health team] [doctor thesis]. São Paulo: Faculdade de Odontologia, Universidade de São Paulo; 2000. Portuguese. 